\title{
Potensi Madu sebagai Terapi Topikal Otitis Eksterna
}

\author{
Yunis Sucipta Ibnu \\ Departemen/ SMF Ilmu Kesehatan Telinga Hidung Tenggorok, Bedah Kepala dan Leher \\ Fakultas Kedokteran Universitas Airlangga-RSUD Dr. Soetomo Surabaya \\ e-mail: yunis.dr@gmail.com \\ phone: +628116840606
}

\begin{abstract}
Abstrak
Otitis eksterna (OE) adalah infeksi Meatus akustikus eksterna (MAE) akibat mikroba karena adanya kerusakan mantel serumen kulit MAE normal yang melindungi dan menjaga kelembapan serta suhu MAE. Hidup di daerah tropis yang hangat dan lembab, penurunan $\mathrm{pH}$ kulit akibat aktivitas dalam air termasuk berenang, dan pembersihan serumen berlebih merupakan faktor predisposisi OE. Penggunaan antibiotika terkonsentrasi secara lokal pada OE dapat tidak hanya menyerang mikroba patogen tapi ikut berdampak bagi flora normal sehingga berpotensi menimbulkan mikroba resisten. Madu memiliki sifat anti bakteri tanpa risiko resistensi bahkan terbukti mampu memodulasi imunitas dan inflamasi. Berbagai penelitian invivo maupun invitro membuktikan bahwa madu memiliki aktivitas anti bakteri berspektrum luas. Madu terbukti secara invitro memodulasi imun dengan mempengaruhi pelepasan berbagai sitokin inflamasi sitokin. Hal ini menunjukkan bahwa madu berpotensi sebagai terapi OE. Artikel ini bertujuan membahas potensi madu sebagai terapi topikal OE dengan harapan dapat menjadi alternatif pilihan terapi dalam tatalaksana OE pada manusia yang aman, efektif, dan efisien.
\end{abstract}

Kata Kunci: potensi madu, terapi topikal, otitis eksterna

\section{Honey Potential as Topical Therapy of External Otitis}

\begin{abstract}
Otitis externa (OE) is an external microbial Meatus acousticus (MAE) infection due to damage to the normal MAE serumen skin coat that protects and maintains MAE moisture and temperature. Living in the warm and humid tropics, a decrease in skin $\mathrm{pH}$ due to activity in the water including swimming, and excess cerumen cleaning are predisposing factors for $O E$. The use of antibiotics locally concentrated in OE can not only attack pathogenic microbes but also have an impact on normal flora so that it has the potential to cause resistant microbes. Honey has anti-bacterial properties without the risk of resistance and has even been shown to modulate immunity and inflammation. Various invivo and invitro studies prove that honey has broad spectrum anti-bacterial activity. Honey is proven invitro to modulate immunity by affecting the release of various inflammatory cytokines. This shows that honey has the potential for $O E$ therapy. This article aims to discuss the potential of honey as a topical $O E$ therapy in the hope that it can be an alternative choice of therapy in the management of $O E$ in humans that is safe, effective, and efficient.
\end{abstract}

Keywords: potential of honey, topical therapy, otitis externa 


\section{PENDAHULUAN}

Otitis eksterna (OE) adalah infeksi Meatus akustikus eksterna (MAE) akibat mikroba karena adanya kerusakan mantel serumen kulit MAE normal yang melindungi dan menjaga kelembaban serta suhu MAE (Lucente \& Linstrom, 2014). Otitis eksterna sering disebabkan oleh keadaan lingkungan dan kebiasaan penderita. Hidup di daerah tropis yang hangat dan lembab, penurunan $\mathrm{pH}$ kulit akibat aktivitas dalam air termasuk berenang, dan pembersihan serumen berlebih merupakan faktor predisposisi (Kolegium THT-KL, 2015). Staphylococcus aureus dan Pseudomonas aeruginosa merupakan mikroba penyebab paling sering. Penggunaan antibiotika terkonsentrasi secara lokal pada OE sering tidak hanya menyerang mikroba patogen tapi ikut berdampak bagi flora normal sehingga berpotensi menimbulkan mikroba resisten. Efikasi terapi topikal melawan organisme resisten merupakan pertimbangan penting seiring peningkatan insiden Staphylococcus resisten obat dan community-acquired strains of Pseudomonas (Rosenfeld, et al., 2014). Terapi yang tidak adekuat merangsang munculnya keluhan ringan yang dapat berlangsung lama seperti rasa gatal sehingga justru semakin mendorong penderita untuk membersihkan telinganya secara berlebihan. Otitis eksterna disebut kronik bila keluhan menetap lebih dari tiga bulan (Mandal \& Mandal, 2011).

Penelitian di poliklinik THTKL BLU RSUP Prof. Dr. R. D. Kandou Manado mengenai pola resistensi bakteri pada pasien OE menunjukkan adanya resistensi antibiotika. Klindamisin dan eritromisin merupakan golongan obat yang paling banyak resistensinya, levofloksasin yang paling sensitif (Suwu, Kountul \& Waworuntu, 2013).Penelitian di rumah sakit Saopaolo Brazil yang dilakukan pada periode 1 Februari 2010 sampai 31 Januari 2011 menunjukan bahwa OE sebagai salah satu penyakit infeksi terbanyak yang datang berobat dengan angka kejadian perbulan mencapai 1558 kasus (urutan kedua) dari 8541 sepuluh diagnosis terbanyak kasus THTKL yang datang berobat ke unit gawat darurat. Kasus $\mathrm{OE}$ paling banyak dijumpai pada bulan Februari dan Januari paling sedikit pada bulan Juli (Werner \& Laccourreye, 2011). Angka kunjungan pasien yang didiagnosis sebagai OE di RSUD Dr. Soetomo Surabaya tahun 1998 sampai 1999 sebanyak 7.667 $(8,88 \%)$ dari 88.166 kunjungan ke poliklinik THTKL (Aryanugraha \& Setiawan, 2012).

Otitis eksterna adalah infeksi akibat terganggunya sistem pertahanan MAE dan kelembaban normal liang telinga. 
ISSN 1978-2071 (Print); ISSN 2580-5967 (Online) Jurnal IImiah Kedokteran Wijaya Kusuma 8(2) : 7-22, September 2019

Kerusakan sistem ini memudahkan invasi bakteri baik karena residu kuman langsung menginvasi akibat benda asing terkontaminasi yang masuk ke MAE seperti cotton bud maupun kuku yang kotor menyebabkan timbulnya inflamasi dan menimbulkan keluhan nyeri, rasa penuh, gatal, dan sekret MAE (Lucente \& Linstrom, 2014).

Madu memiliki sifat anti bakteri tanpa risiko resistensi bahkan terbukti mampu memodulasi imunitas dan inflamasi (Kwakman \& Zatt, 2012; Boukra, 2014). Penelitian membuktikan bahwa madu memiliki aktivitas anti bakteri berspektrum luas. Madu adalah pengobatan kuno untuk terapi kulit terinfeksi yang kembali menjadi harapan ketika agen terapi modern mulai menunjukkan kegagalan bahkan madu terbukti mampu melawan bakteri resisten seperti methicillin-resistant Staphylococcus aureus (MRSA) (Mandal \& Mandal, 2011). Madu terbukti memiliki aktivitas anti mikroba pada infeksi telinga yang disebabkan oleh haemofilus influenza (Boukraa, 2014). Laporan kasus OE kronik akibat infeksi Pseudomonas aeruginosa yang resisten penisilin, kuinolon, sefalosporin bahkan aminoglikosid oral maupun parenteral sebagai tetes telinga pada anjing menunjukkan keberhasilan terapi setelah menggunakan tetes telinga madu Khadikraft India (Sooryadas \& Deepthy, 2013).

Proses inflamasi MAE terbukti diperankan oleh berbagai mediator inflamasi. Interleukin 1 (IL-1) adalah sitokin yang ekspresinya dijumpai pada epidermis MAE normal dan memiliki peran dalam mengatur faktor pertumbuhan autokrin sel epitel. Schilling et. al. tahun 1992 meneliti tentang ekpresi IL-1 $\alpha$ dan IL-1 $\beta$ yang positif pada epidermis MAE. Bujia et al. tahun 1997 menemukan resptor IL-1 yang tersebar merata pada MAE (Caliman, et al., 2008). Madu terbukti secara invitro memodulasi imun dengan mempengaruhi pelepasan sitokin jalur sel monosit Mono Mac 6 (MM6) dan human periferal monosit setelah inkubasi dengan madu. Madu juga menginduksi pelepasan IL-6, IL1 $\beta$. Madu menginduksi TNF-á melalui Toll-like receptor 4 . Molekul ini juga menginduksi IL-1á dan IL-6. Hal ini menunjukkan bahwa madu memiliki potensi menghambat proses inflamasi MAE (Boukraa, 2014).

Berbagai penelitian tersebut menunjukkan bahwa madu berpotensi sebagai terapi OE. Madu telah disetujui penggunaannya dalam terapi medis oleh Food and Drug Administration (FDA) tahun 2007 (Nori, Salom \& Ahmad, 2011). Tinjauan pustaka ini bertujuan membahas potensi madu sebagai terapi topikal $\mathrm{OE}$ dengan harapan menjadi alternatif pilihan 
terapi dalam tatalaksana OE yang aman, efektif, dan efisien.

\section{KAJIAN PUSTAKA}

\section{Madu dalam Ethnomedicine}

Madu telah digunakan sebagai obat oleh bangsa Yunani bahkan Mesir kuno (Pyrzynska \& Biesaga, 2009). Manfaat madu telah tertulis pada prasasti Sumerian 2100-2000 sebelum masehi, madu digunakan untuk obat minum maupun topikal. Aristoteles (384-322 S.M.) menyebutkan bahwa madu berwarna pucat sebagai "good as a salve for sore eyes and wounds" (Mandal \&Mandal, 2011). Madu merupakan minuman kaya nutrisi penting bagi kesahatan manusia yang bermanfaat dalam penyembuhan luka karena memiliki efek antioksidan, anti inflamasi, dan bakteriostatik (Suarez, et al., 2014). Aktivitas anti bakteri madu secara ilmiah pertama dilaporkan pada tahun tahun 1892 yang digunakan untuk terapi dan pencegahan infeksi pada luka (Kwakman \& Zatt, 2012). Madu sudah digunakan untuk terapi inflamasi tenggorok dan tonsil 50 tahun sebelum masehi (Boukraa, 2014).

\section{Otitis Eksterna}

\subsection{Patogenesis dan gejala klinis}

Tiga mekanisme pertahanan anatomik MAE yaitu tragus dan anti tragus, kulit dengan serumennya, serta ismus kanal MAE. Kulit pars kartilagenus mengandung banyak sel rambut, kelenjar sebaseus, dan apokrin seperti kelenjar serumen (Gambar 1).

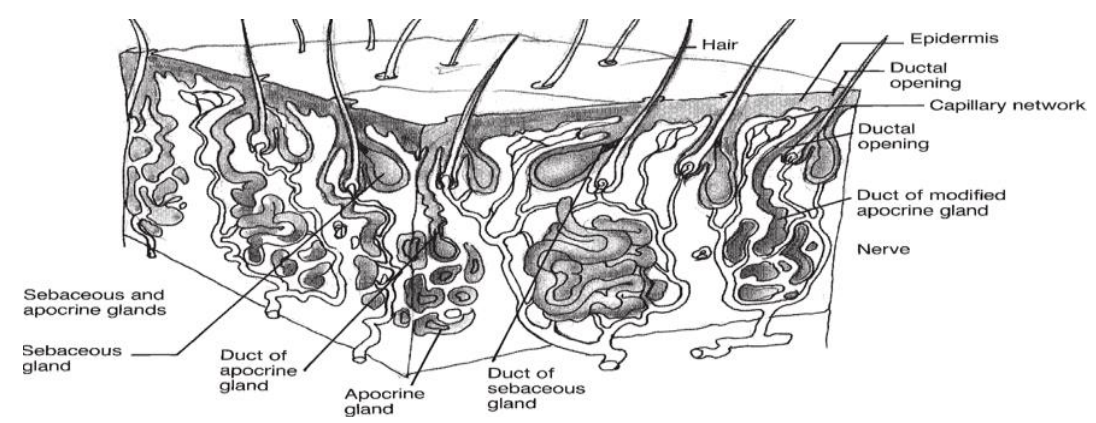

Gambar 1. Mikroskopis apopilosebaseus kulit MAE dengan drainase ke folikel rambut modifikasi dari glandula apokrin penghasil serumen (Lucente \& Linstrom, 2014)

Ketiga struktur adneksa tersebut membentuk fungsi perlindungan yang disebut unit apopilosebaseus. Sekresi kelenjar kombinasi dengan jaringan epitel skuamus yang mati pada permukan MAE membentuk lapisan asam serumen yang merupakan suatu barier utama infeksi MAE (Lucente \& Linstrom, 2014).

Gejala klinis OE sangat bergantung pada patogenesis yang terjadi sesuai stadium. Stadium preinflamasi dimulai ketika stratum korneum menjadi edema 
karena hilangnya lapisan lipid protektor dan mantel asam dari MAE sehingga menyebabkan plugging unit apopilosebaseus. Obstruksi yang berlanjut menimbulkan sensasi rasa penuh dan gatal. Kerusakan lapisan epitel memudahkan invasi bakteri pada MAE maupun mengendapnya benda asing ke dalam kanal. Hal ini menyebabkan terjadinya stadium inflamasi akut yang menimbulkan keluhan nyeri dan edema MAE. Tahapan paling awal stadium ini kulit menjadi sedikit eritema dan edema. Sekret kelabu minimal dijumpai pada MAE.

Nyeri dan rasa gatal yang semakin meningkat menyebabkan pasien memasuki tahap inflamasi sedang. Meatus akustikus eksternus edema dan eksudat menjadi lebih banyak. Proses yang berlanjut tanpa pengobatan menyebabkan pasien sampai pada inflamasi berat dengan gejala klinis peningkatan rasa nyeri, buntu MAE, eksudat purulen, dan edema kulit MAE yang dapat meluas ke membran timpani (MT). Papula putih sering dijumpai pada permukaan MAE. Pseudomonas aeruginosaatau basilus gram negatif lain sering dijumpai pada kultur stadium inflamasi. Perluasan infeksi MAE mengenai jaringan lunak dan kelenjar limfe leher dapat terjadi (Lucente \& Linstrom, 2014).

Stadium kronis menunjukkan gejala radang yang mereda namun berlangsung lama. Nyeri tidak lagi dirasakan pada stadium kronik, rasa gatal lebih menonjol sebagai keluhan pasien. Kulit MAE menebal dan terkelupas. Aurikula dan konka sering menunjukkan ruam sekunder seperti eksematisasi, likenifikasi dan ulkus superfisial. Keadaan ini mirip eksema mulai dari kulit kering ringan dan penebalan MAE sampai ke obstruksi total MAE akibat infeksi kronik menyebabkan hipertropi kulit (Lucente \& Linstrom, 2014).

\subsection{Tatalaksana}

\subsubsection{Diagnosis}

American Academy Otorhinolaryngology Head and Neck Surgery (AAO-HNS) menyusun kriteria diagnosis OE difusa akut yang didasari atas onset cepat disertai tanda inflamasi MAE. Onset 48 jam berlangsung selama kurang dari tiga minggu dan simtom inflamasi meliputi otalgia yang sering berat, gatal, atau sensasi penuh pada MAE. Gejala tersebut disertai atau tanpa penurunan pendengaran maupun nyeri rahang bawah bila temporo mandibular joint (TMJ) digerakkan (Rosenfeld, et al. 2014). Dijumpai tanda inflamasi MAE yaitu nyeri tragus, aurikula atau keduanya atau edema difus MAE, eritema atau keduanya dengan atau tanpa otore, limfadenitis regional, eritema membran timpani atau selulitis aurikula dan kulit sekitarnya (Gambar 2). 

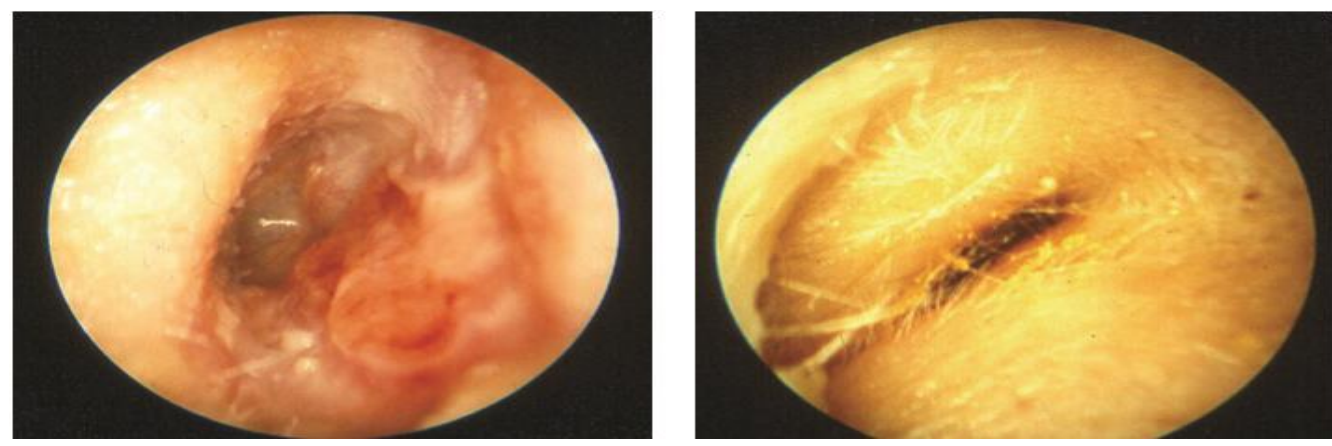

Gambar 2. Gambaran otoskopi menunjukkan edema dan eritema MAE (A dan B)

(Rosenfeld, et al. 2014; Scaefer \& Baugh, 2012)

\subsubsection{Terapi}

Terapi OE akut didasari atas tujuan memperbaiki gejala otalgia, gatal, dan sensasi penuh pada MAE dalam 48-72 jam terapi. Penyembuhan total dapat terjadi sampai dengan dua minggu terapi.
Kegagalan terapi dapat disebabkan oleh obstruksi kanal MAE, ketidakpatuhan menjalani terapi, kesalahan diagnosis, faktor mikrobiologis, faktor host atau kontak sensitivitas terhadap tetes telinga (Gambar 3).

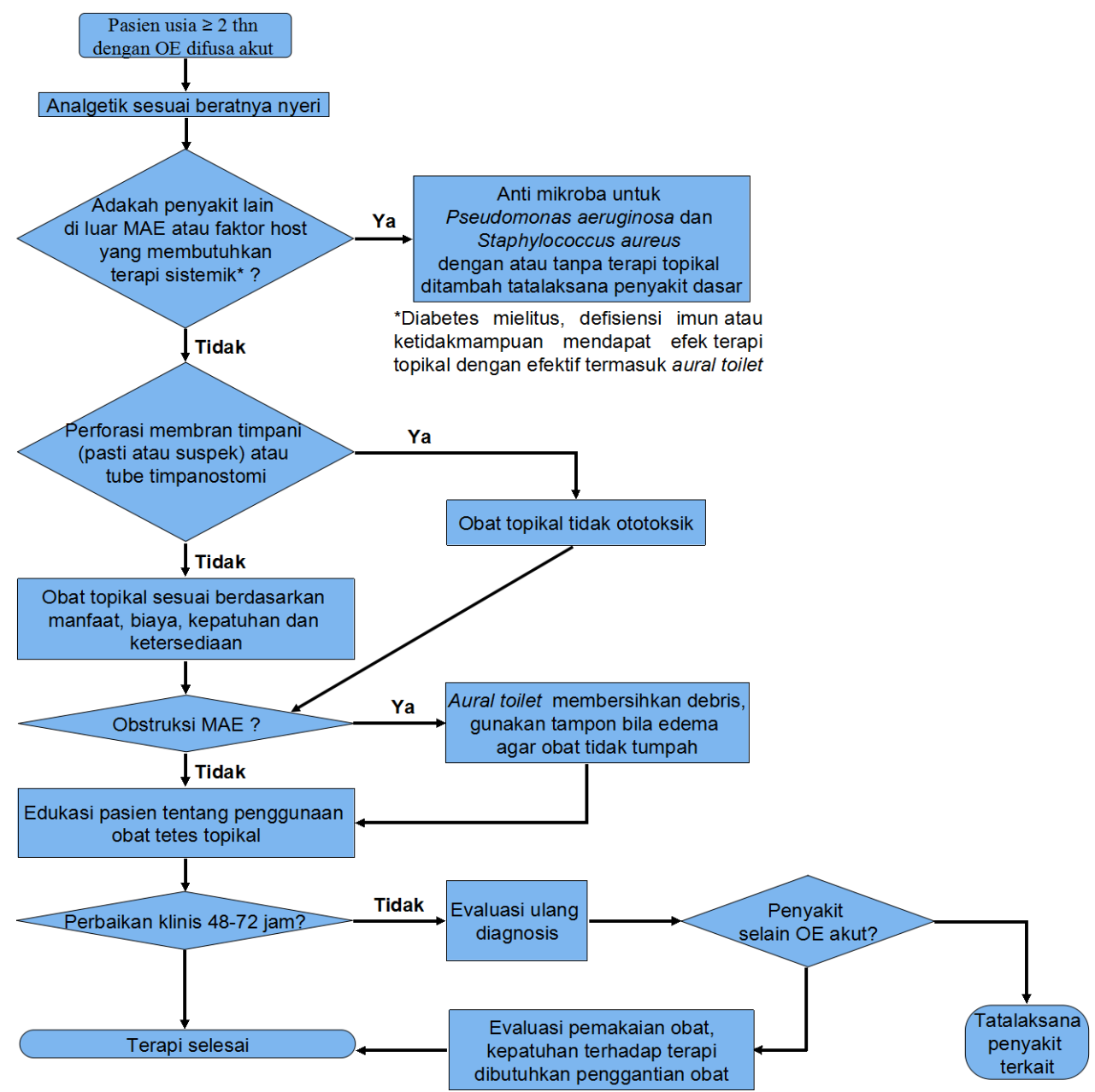

Gambar 3. Diagram tatalaksana OE akut (Rosenfeld, et al., 2014) 
ISSN 1978-2071 (Print); ISSN 2580-5967 (Online) Jurnal IImiah Kedokteran Wijaya Kusuma 8(2) : 7-22, September 2019

Terapi topikal yang dianjurkan berupa aminoglikosida, polimiksin $B$, kuinolon atau kombinasi dengan steroid hidrokortison atau deksametason, dan antiseptik $\mathrm{pH}$ rendah (Rosenfeld, et al. 2014). Empat kunci utama terapi pada semua stadium OE yaitu pembersihan MAE berkala sesering mungkin, penggunaan antibiotik relevan, terapi inflamasi dan nyeri, serta kontrol berkala. Antibiotika tetes telinga diberikan minimal sampai tiga hari bebas nyeri, gatal, dan sekret sehingga menjamin eradikasi infeksi (Lucente \& Linstrom, 2014). Kombinasi tetes telinga antibiotik dengan steroid tetes telinga dapat diberikan namun tidak boleh lebih dari dua minggu. Pemberian lebih dari dua minggu dapat menyebabkan resistensi (Kolegium, THTKL 2015).

Terapi stadium preinflamasi menggunakan kompres tampon burowi yang dibasahi setiap4-6 jam selama 2 hari. Stadium inflamasi ringan, sedang, dan berat dengan ear toilet berkaladengan asam borat, asam asetat, dan burowi. Pilihan obat yang digunakan yaitu antihistamin diberikan bila alergi sebagai penyebab, tetes telinga mengandung Neomisin 0,5\%, Polimiksin B sulfat dan steroid (PDT).

\subsection{Potensi Madu}

\subsubsection{Komposisi madu}

Komposisi madu tergantung jenis, iklim, dan cuaca sekitar tanaman sumber nektar. Polifenol adalah salah satu kandungan utama madu yang berperan dalam inflamasi dan infeksi. Madu berwarna gelap memilki kandungan fenolik lebih tinggi sehingga memiliki kemampuan anti oksidan yang lebih kuat (Pyrzynska \& Biesaga, 2009).

Fenol madu Manuka mampu menghambat pertumbuhan Staphylococcus aureus. P. Aeruginosa, E. Coli, dan Bacillus subtilis. Polifenol berupa fenolik dan flavanoid yang merupakan senyawa penting bersumber dari tanaman. Flavanoid dapat dikelompokkan sebagai flavanols, flavaones, flavones, anthocyanids, dan isoflavones (Gambar 9) dan memiliki berbagai efek biologi yaitu anti bakterial, anti inflamasi serta anti alergi. Flavanoid berperan sebagai anti oksidan melalui bermacam cara termasuk direct trapping of reactive oxygen species, menghambat enzim yang memproduksi anion superoksida, kelasi transisi metal dalam pembentukan radikal bebas dan pencegahan proses peroksidase dengan mengurangi radikal alkoksil dan peroksil.

\subsubsection{Efek madu}

Madu memiliki kemampuan eradikasi infeksi dengan berbagai potensi yang dimilikinya. Madu memiliki kemampuan menciptakan lingkungan yang 
buruk bagi mikroba. Kemampuan madu meningkatkan pelepasan sitokin dan memodulasi aktivitas imun menyebabkannya mampu memperkuat imunitas tubuh dalam melawan mikroba (Boukraa, 2014).

Madu bekerja sebagai anti mikroba karena efek asiditas, osmotik, hidrogen peroksida (H2O2), dan faktor pitokimia. Adanya faktor bakteriostatik dan bakterisida yaitu H2O2, lisozim, asam fenolik, anti oksidan, flavonoid, methylglioxal (MGO), dan polifenol yang meningkatkan pelepasan sitokin dan memodulasi imunitas sehingga berperan sebagai anti mikroba. Madu adalah cairan gula supersaturasi sehingga menganggu pertumbuhan mikroba.

Faktor yang berkontribusi dalam aktivitas anti mikroba madu yaitu $\mathrm{H} 2 \mathrm{O} 2$, MGO, anti mikroba peptida defensin-1, dan $\mathrm{pH}$ yang rendah. Bee defensin-1 yang dihasilkan oleh glandula hipofaring lebah madu memiliki aktivitas poten tapi hanya melawan bakteri gram positif Staphylococcusaureus, dan Paenibacillus larvae. Netralisasi MGO menghilangkan aktivitas madu manuka terhadap Staphylococcusaureus dan secara substansial mengurangi aktivitas terhadap B. subtilis tapi tidak mempengaruhi aktivitas terhadap Escherichia coli dan Psudomonas aeruginosa. Hidrogen peroksida berfungsi untukmencegah pembusukan madu mentah ketika konsentrasi gula belum mencapai tingkat mampu mencegah pertumbuhan mikroba (Kwakman \& Zatt, 2012).

\subsubsection{Pemakaian sistemik}

Inflamasi adalah upaya pertahanan tubuh melawan agen infeksi. Inflamasi akut ditandai dengan edema, panas, hiperemi, nyeri, dan gangguan fungsi akibat infiltrasi jaringan oleh plasma dan leukosit (Hussein, et al., 2013). Madu mampu mengurangi edema dan eksudat (Boukraa, 2014). Madu Tualang terbukti memiliki efek anti inflamasi, mempercepat penyembuhan luka dengan mengurangi edema, inflamasi, dan eksudat yang umumnya terbentuk pada seluruh tipe luka dengan menstimulasi pertmbuhan sel epitel dan fibroblas. Sifat anti inflamasi madu Tualang mampu menyamai terapi konvensional dengan luka pada penelitian terhadap kelinci (Othman, et al., 2015). Madu Gelam satu atau $2 \mathrm{gr} / \mathrm{Kg} \mathrm{BB}$ mampu menurunkan dengan signifikan infiltrasi sel-sel inflamasi dan skor inflamasi dibandingkan indometasin $10 \mathrm{mg} / \mathrm{kgBB}$ pada inflamasi yang dinduksikan pada hewan coba dalam 24 jam pertama pemberian secara oral (Hussein, et al. 2013).

Mediator proinflamasi yang dilepas saat terjadi inflamasi diantaranya iNOS, COX-2, TNF-á, dan IL-6. Induksi mediator 
proinflamasi diatur oleh aktivasi transkripsi. NF-kB yang dikenal sebagai faktor utama transkripsi regulator gen ekspresi respon mediator proinflamasi. Protein NF-kB, p65, dan p50 dalam keadaan normal dijumpai pada sitoplasma sebagai kompleks tidak aktif yang mengikat faktor inhibitor IkBa sehingga memblok translokasi nukleus NF-kB. Adanya stimulus inflamasi, IkBa difosforilasi oleh IkB kinase (IKK) dan dipecah dari subunit NF-kB sehingga mendegradasikannya. NF-kB yang bebas ditranslokasi ke dalam nukleus berperan sebagi faktor transkripsi. NF-kB dimers bergabung dengan target elemen DNA dalam nukleus untuk mengaktivasi gen transkripsi yang mengkode protein inflamasi yang terlibat pada proses inflamasi (Hussein, et al., 2013).

Aktifasi NFkB meregulasi transkripsi IL-1 $\beta$, IL-6, iNOS, COX-2, dan TNF- $\alpha$ dengan demikian mereduksi inflamasi, fokus utama dengan meghambat aktivasi NF-kB dan translokasinya ke dalam nukleus sehingga menurunkan produksi mediator proinflamasi. Polifenol yang dikandung madu Gelam pada berbagai penelitian invitro dan invivo terbukti mengurangi aktivasi jalur NF-KB. Madu Gelam menghambat translokasi dan aktivasi NFkB dalam nukleus dan menurunkan degradasi IkBa dalam sitosol. Ekspresi imunohistokimia mediator proinflamasi
COX-2 dan TNF- $\alpha$ juga dikurangi oleh madu Gelam.

Efektifitas madu sebagai anti bakteri dikarenakan dua hal yaitu sifat fisikokimiaanya dan komponen pitokimianya (Boukraa, 2014). Fisikokimia; Madu memiliki efek anti bakteri karena osmolaritasnya yang tinggi, $\mathrm{pH}$ rendah dan $\mathrm{H} 2 \mathrm{O} 2$ yang dikandungnya. Aktivitas air yang rendah menghambat pertumbuhan mayoritas bakteri. Madu bersifatasam dengan $\mathrm{pH}$ antara 3,2 sampai 4,5 sehingga menghambat cukup banyak bakteri patogen, termasuk pada pemakaian topikal. Hidrogen peroksida dijumpai sebgai anti mikroba utama yang dikandung madu yang diproduksi dari glukosa oleh glikose oksidase menghasilkan asam glukonik. Hidrogen peroksidamemiliki kemampuan membersihkan luka (Boukraa, 2014). Pitokimia madu; Methylglioxal adalah komponen bioaktif pertama yang dikenal dan konsentrasinya berkorelasi dengan aktivitas non peroksidase madu. Fenolik memiliki kemampuan anti karsinogenik, anti inflamasi, anti iatrogenik, anti trombotik, imunomodulator, analgetik, dan anti oksidan (Boukraa, 2014).

Madu memiliki sifat anti virus. Hidrogen peroksida dan MGO adalah komponen utama anti virus yang dikandung madu. Madu menghambat replikasi virus. Metilglioksal adalah 
komponen madu yang mengeradikasi Respiratory Syntical Virus (RSV) (Boukraa, 2014). Madu menciptakan lingkungan yang buruk bagi mikroba. Madu memiliki sifat asiditas dan hiperosmolar yang menciptakan lingkungan yang tidak baik untuk pertumbuhan mikroba (Noori, Salom \& Ahmad, 2012). Madu bahkan memiliki kemampuan sebagai antiseptik. Madu adalah cairan gula hipersaturasi $84 \%$ campuran fruktosa dan glukosa (Gull, et al., 2014). Kandungan gula madu terutama glukosa, fruktosa, sukrosa, dan maltosa serta mengandung $<18 \%$ air. Konsentrasi molekul gula yang tinggi ini menjadikan sangat sedikit ketersediaan molekul air untuk mikroorganisme sehingga mengurangi pertumbuhan mikroba (Kwakman \& Zatt, 2012; Gull, et al.,2014). Tingginya kandungan hidrogen peroksida merupakan hal penting bagi madu. Hidrogen peroksida diproduksi saat glukosa oksidasi dikatalisasi oleh glukose oksidase. Tingginya Hidrogen peroksida di lingkungan bakteri mengganggu respon bakteri terhadap sinyal proliferasi sehingga pertumbuhan bakteri berhenti (Afroz, et al.,2016).

Madu adalah bahan pangan sehinga tidak ada batasan dosis dalam penggunaannya (BPOM, 2015). Madu sebaiknya tidak digunakan pada luka terbuka yang mengekspose kartilago.
Seperti yang dikutip werner dari Harshemi et al., perikondritis terjadi pada luka bakar aurikula yang diterapi dengan madu pada tikus percobaan (Werner, 2011). Madu tidak boleh digunakan pada telinga dengan perforasi MT. Madu bersifat ototoksik bila masuk ke dalam kavum timpani. Pemeriksaan Auditory brainstem evoked respones ( $A B R$ ) menunjukkan ototoksisitas madu Manuka konsentrasi 50\%. Pemeriksaan mikroskopik dijumpai perubahan pada sel rambut koklea (Aroon, et. al., 2012).

Madu tidak boleh digunakan pada anak berusia kurang dari satu tahun karena risiko botulism. Madu dapat mengandung spora Clostridium botulinum. Spora Clostridium botulinum mampu bertahan dalam madu namun tidak dapat menghasilkan toksin. Spora ini akan mati dengan radiasi gamma dosis rendah. Penelitian di berbagai negara tidak membuktikan bahwa infeksi botulism disebabkan karena pemakaian madu pada dewasa (Werner, 2011). Sistem imun anak usia 12 tahun keatas sudah mampu menetralisir toksin dan spora Clostridium botulinum yang masuk ke dalam tubuh sehingga Clostridium botulinum tidak mampu memberikan efek botulisme (Bogdanov, 2016).

Madu aman digunakan tanpa terjadi botulisme pada terapi mukositis, luka di 
ISSN 1978-2071 (Print); ISSN 2580-5967 (Online) Jurnal IImiah Kedokteran Wijaya Kusuma 8(2) : 7-22, September 2019

leher, dan faringostome seperti yang dikutip werner dari descottes 2009 (Werner, 2011). Insiden botulism yang kecil menyebabkan otoritas makanan dan obat di eropa tidak mengeluarkan peringatan botulisme untuk penggunaan madu (Bogdanov, 2016).

\section{PEMBAHASAN}

\subsection{Pemakaian topikal madu pada OE}

\subsubsection{Pemakaian invitro pada hewan}

Penelitian invitro Mello D menilai efektivitas madu Tetragonisca angustula terhadap mikroorganisme yang dijumpai pada MAE anjing yang mengalami OE. Kultur primer didapatkan Staphylococcus sp., Bacillus sp dan jamur. Tampak tidak ada pertumbuhan kuman anti biogram madu Tetragonisca angustula (gambar 4B). Madu Tetragonisca angustula hanya mampu diungguli oleh sefaleksim (Gambar
4A). Ini menunjukkan bahwa madu terbukti memiliki potensi yang istimewa dalam melawan bakteri penyebab infeksi dan inflamasi MAE.

\subsubsection{Pemakaian invivo pada hewan}

Penelitian invivo pada Canis familiaris dan Felis catus dengan kultur jamur Malassezia pachydermatis menggunakan madu Tetragonisca angustula yang diaplikasikan pada telinga sampel. Seluruh sampel dapat mentoleransi pemakaian madu. Madu memperlihatkan aktivitas pada otitis eksterna dan efektif mengontrol Malassezia spp. Hal in terjadi karena $\mathrm{pH}$ Tetragonisca angustula asam (3.27) menghambat pertumbuhan Malassezia spp dan Staphylococcus spp. yang $\mathrm{pH}$ optimal untuk pertumbuhanya 5 sampai 7. Akivitas anti jamur secara invitro seperti terlihat pada (Gambar 4).

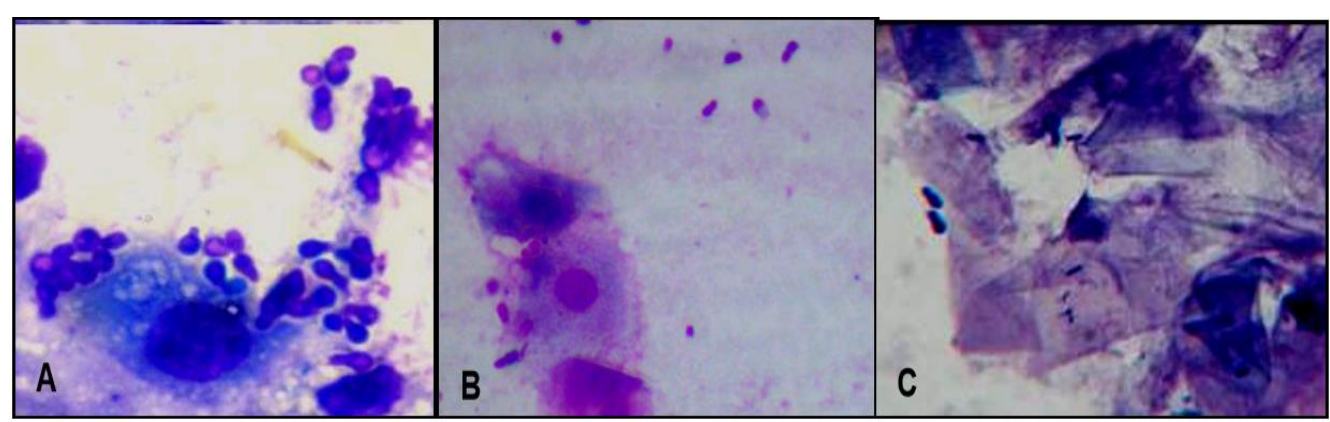

Gambar 4. Pengecatan dengan gram menunjukkan Malassezia spp: hari ke-3 (A), ke 7 (B), dan ke-10 (C) terapi dengan madu Tetragonisca angustula terbukti mengurangi pertumbuhan jamur (Bobany \& Martins, 2013).

3.1.3 Potensi penggunaan topikal pada manusia

Aplikasi topikal madu untuk Infeksi kulit MAE dapat mengeradikasi mikroba patogen seperti Stafilococcus aureus, MRSA, Pseudomonas aeruginosa, E. coli, Candida albican dapat mengatasi gejala inflamasi yang ditimbulkannya (Sooryadas 
\& Deephty, 2013; boukra, 2014; Robert, Brown \& Jenkins, 2015; Bogdanov, 2016; Devasravaran \& Yoke, 2016). Otitis Eksterna dapat timbul akibat terganggunya kelembaban dan pH normal MAE. Madu mampu mengembalikan kelembaban luka. Madu memiliki viskositas yang tinggi sehingga dapat berperan sebagai barier dan melindungi luka dari infeksi. Mekanisme tersebut karena $\mathrm{pH}$ madu yang rendah dan kadar gula tinggi (osmolaritas tinggi) mencegah petumbuhan mikroba. Madu bersifat higroskopik artinya madu mampu mengeringkan lingkungan sehingga menyebabkan bakteri dehidrasi. Kadar gulanya yang tinggi dan $\mathrm{pH}$ yang rendah mencegah pertumbuhan bakteri (Mandal \&
Mandal, 2011; Werner \& Laccourreye, 2011).

Bakteri patogen yang sering menyebabkan OE akut yaitu

Pseudomonasaeruginosa,

danStaphylococcus aureus (Lucente \& Linstrom, 2014). Kemampuan madu Manuka melisis Pseudomonasaeruginosa terkait dengan protein membran paeruginos yaitu protein $\mathrm{F}(\mathrm{OprF})$. Protein ini memiliki fungsi vital menjaga integritas membran luar dengan lapisan peptodoglikan dibawahnya sehingga menjaga hemostasis amplop dan bentuk sel yang teratur. Berkurangnya ekspresi OprF akibat madu Manuka menimbulkan blebs dinding sel dan lisis sel Pseudomonas aeruginosa (Gambar 5).

Regular cell function

Loss of cell function

Irreversible cell damage

Outer membrane protein $\mathrm{F}(\mathrm{OprF})$ is protein that ensures regular cell shape and envelope homeostasis with various porin functions and is required for the full virulence of $P$. aeruginosa. reduction in membrane stability and
When treated with manuka honey, there is a significant reduction in the expression of OprF. This leads to a blebbing of the outer membrane as it dissociates from the underlying peptidoglycan layer.

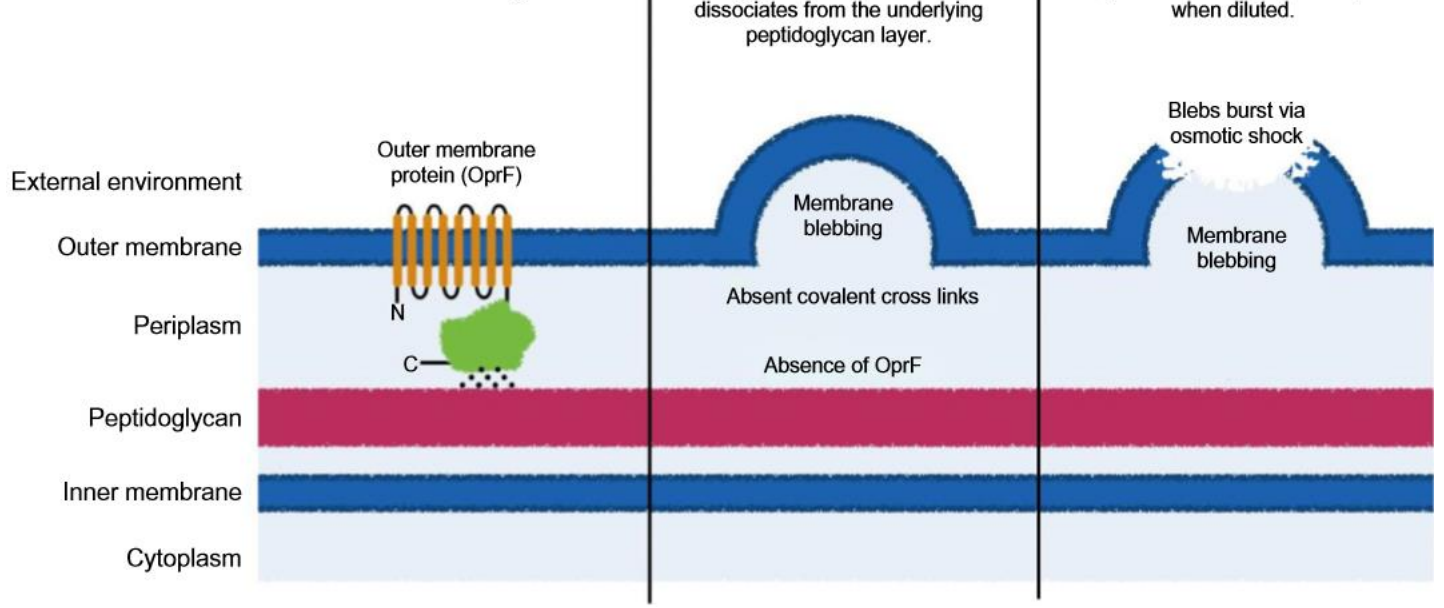

Gambar 5. Cara kerja madu Manuka menghambat Pseudomonas aeruginosa. Madu Manuka menyebabkan amplop sel tidak stabil dengan cara merusak protein OprF yang menjaga kestabilan bentuk amplop sel Pseudomonas aeruginosa. Hilangnya protein tersebut akibat madu Manuka menyebabkan terbantuknya blebs dan menurunkan viabilitas sel sehingga menjadi lisis (Robert, Brown \& Jenkins, 2015). 
ISSN 1978-2071 (Print); ISSN 2580-5967 (Online) Jurnal IImiah Kedokteran Wijaya Kusuma 8(2) : 7-22, September 2019

Madu Manuka telah banyak dilaporkan oleh berbagai penelitian bersifat sebagai bakteriostatik terhadap Staphylococcus aureus. Sel-sel bakteri membelah dan hsail pembelahan kromosomnya membentuk suatu cincin protein pada bagian tengah sel membentuk dua sel anakan baru bila lingkungan optimal. Pembagian sel selesai bila peptidoglikan (murein) hidrolase mendegradasi dinding sel diantara kedua sel anakan tersebut hingga keduanya saling terpisah. Madu manuka terbukti menunjukkan kemampuannya menghambat aktivitas murein hydrolase, menyebabkan terbentuknya sel bakteri bersepta utuh dan tidak membelah.

Pemakaian madu secara topikal diawali dengan pembersihan kulit terinfeksi menggunakan cairan fisiologis. Kulit yang terinfeksi dikompres basah dengan madu. Evaluasi dilakukan setiap 48 jam kemudian dicuci dengan cairan fisiologis (Werner, 2011). Madu Manuka menunjukkan aktivitas anti bakteri dengan aplikasi madu murni. Madu dengan pengenceran aktif menunjukkan kerjanya pada pengenceran $20 \% \quad-\quad 80 \%$. Pengenceran $80 \%$ memiliki efek anti mikroba paling baik sehingga hal ini membuktikan bahwa semakin murni maka madu semakin efektif dalam eradikasi mikroba patogen (Mohamed, et al., 2010;
Alqurashi, Masoud \& Alamin, 2013). Pengenceran dilakukan dengan menambahkan sterile distilled water 1,2 , 4, 6 atau $8 \mathrm{ml}$ untuk menghasilkan sediaan $10 \mathrm{~mL}$ (Alqurashi, Masoud \& Alamin, 2013; Bogdanov, 2016). Sooryadas dan Deepthy menggunakan $2 \mathrm{ml}$ madu yang diteteskan pada telinga anjing yang mengalami $\mathrm{OE}$. Aplikasi dilanjutkan sampai satu minggu bebas gejala OE (Sooryadas \& Deepthy, 2013).

Gejala klinis OE harus mulai membaik dalam waktu 48 sampai dengan 72 jam pertama dan penyembuhan terjadi dalam 2 minggu terapi (Rosenfeld, et al., 2014). Penelitian Maruhashi membuktikan bahwa secara invitro madu mampu menghentikan seluruh aktivitas biosidal mikroba dalam waktu lima sampai sepuluh menit pertama aplikasi (Maruhashi, et al., 2016). Penelitian terapi OE yang disebabkan oleh jamur maupun bakteri membuktikan terjadi perbaikan secara sitologi maupun klinis pruritus $70 \%$ sampel antara hari ke 7 dan 14 serta 90\% sampel pada hari ke 21 dengan penggunaan madu topikal sebagai terapi. Seluruh sampel dapat mentoleransi aplikasi topikal madu tersebut (Maruhashi, et al., 2016). Kemampuan madu sebagai anti mikroba, anti inflamasi dan mempercebat penyembuhan tanpa menyebabkan resistensi, hal ini menunjukkan bahwa 
madu dapat memiliki potensi memberikan prognosis yang baik dalam penyembuhan infeksi dan inflamasi pada OE (Mandal \& Mandal, 2011).

\section{KESIMPULAN}

Otitis eksterna adalah infeksi MAE akibat terganggunya sistem pertahanan MAE yaitu lapisan lemak dan mantel serumen pelindung kanal menyebabkan pluging unit apopilosebaseus MAE sehingga mengganggu kelembapan MAE. Klinis OE dibagi sesuai stadium yaitu preinflamasi; inflamasi akut yang ringan, sedang dan berat, serta stadium inflamasi kronik. Madu berpotensi mengurangi inflamasi dalam 48-72 jam pertama terapi karena menunjukkan kemampuan madu menghentikan aktivitas mikroba sejak 10 menit pertama dan mampu menghambat mediator pro inflamasi dalam 24 jam terapi. Madu bekerja sebagai anti mikroba tanpa menimbulkan resistensi. Madu mengembalikan kelembapan, $\mathrm{pH}$, dan kekeringan MAE sehingga menciptakan lingkungan yang buruk untuk pertumbuhan dan perkembangan mikroba patogen. Madu merupakan bahan alami yang terbukti aman digunakan pada MAE dalam berbagai penelitian hewan coba. Madu telah mendapat lisensi untuk digunakan dalam terapi medis pada manusia sehingga madu berpotensi untuk digunakan sebagai terapi topikal OE.

\section{DAFTAR PUSTAKA}

Afroz R, Tanvir EM, Zheng W, Litte PJ, 2016. Molecular pharmacology of honey, Clin Exp Pharmacol 6:1-13

Aron $\mathrm{M}$, Victoria AO, Dorin D, Daniel S, 2012. Otologic safety of manuka honey, J Otolaryngol Head Neck Surg 41: S21-30

Alqurashi AM, Masoud EA, Alamin MA, 2013. Antibacterial activity of saudi honey against gram negative bacteria, Journal of Microbiology and Antimicrobials 5(1): 1-5

Aryanugraha PT, Setiawan EP, 2012. Kejadian otitis eksterna pada masyarakat penebel tabanan dan yangapi bangli yang berkunjung ke bakti sosial staf medis fungsional telinga hidung tenggorokan fakultas kedokteran universitas udayana - rumah sakit umum pusat sanglah pada tahun 2012, ISM 5(1):60-63

Bobany DM, Martins RRC, 2013. Antimicrobial natural products: apitherapy, Formatex: 940-945

Bogdanov S, 2016. Honey in medicine, Bee Product Science, www.beehexagon.net 
ISSN 1978-2071 (Print); ISSN 2580-5967 (Online) Jurnal IImiah Kedokteran Wijaya Kusuma 8(2) : 7-22, September 2019

Boukraa L, 2014. Honey in traditional and modern medicine. London: CRC Press, pp. 37-57

Badan Pengawas Obat dan Makanan, 2015. Penyalahgunaan madu, propolis, dam bee pollen, Naturakos 10(29): 5-6

Caliman JDC, Riberio FAQ, Pereira GS, Alves AL, 2008. Immunohistochemistry of external auditry canal: systemic review, Int. Arch. Otolaryngol 12(2):258-73

Departemen Agama, 2010. Al-Qur'an tajwid dan terjemah. Bandung: CV Penerbit Diponegoro, pp. 26781

Devasravaran K, Yoke-KY, 2016. Anti inflammatoryand wound healing properties of malaysia tualang honey, Current Science 110(1): 47-51

Gul W, Farooq N, Khan U, Rehan F, Anees D, 2015. Honey: a nectarous anti infective agent, World Journal of Phamaceutical Sciences 4(4):20815

Hussein SZ, Yusoff KM, Makpol S, Yussof YAM, 2013. Gelam honey attenuates carrageenan-induced rat paw inflammation via nf-kb pathway, Plos One 8(8):1-12
Kolegium Ilmu Kesehatan T.H.T.K.L, 2015. Modul I.4 Inflamasi telinga luar, Edisi II, Jakarta

Kwakman PHS, Zaat SAJ, 2012. Antibacterial componen of honey, Life,64(1):48-55

Lucente FE, Linstrom CJ, 2014. Disease of the external ear. In: Johnson JT, Rosen CA, Newlands S, Amin M, Branstetter B, Casselbrant $M$, et al., eds. Bailey's head and neck surgery otolaryngology, 5th edition, Vol 2, Philadelphia: Lippincott Williams \& Wilkins, pp. 2333-57

Mandal MD, Mandal S, 2011. Honey: its medicinal property and antibacterial activity, Asian Pac J Trop. Biomed 1(2):154-60

Maruhashi E, Braz BS, Nunes T, Pomba C, Belas A, Henrique J, et al., 2016. Efficacy of medical grade honey in the management of canine otitis externa-a pilot study, Vet Dermatol 10:1-8

Mohamed M, Sirajudeen KNS, Swamy M, Yacoob NS, Sulaiman SA, 2010. Studies on the antioxidant properties of tualang honey of malaysia, Afr. J. Trad. CAM 7(1):59-63

Nayik GA, Shah TR, Muzaffar K, Wani SA, Gull A, Majid I, et al., 2014. 
Honey: its history and religious significance: a review, UJP 3(1):58

Noori AW, Salom K, Ahmad AA, 2011. Honey for wound healing, ulcers, and burns; data suporting its use in clinical practice, The Scientific World Journal 11:766-87

Othman Z, Zakaria R, Hussein NHN, Hassan A, Shafin N, Badriya AR, et al., 2015. Potential role of honey in learning and memory, Med Sci 3:3-15

Pyrzynska K, Biesaga M, 2009. Analysis of phenolic acids and flavanoids in honey, Trends in Analitical Chemistry 28:893-902

Robert AEL, Brown HL, Jenkins RE, 2015. On the antibacterial effects of manuka honey: mechanistic insights, Research and Reports in Biology 6:215-24

Rosenfeld RM, Schwartz SR, Cannon CR, Roland PS, Simon GR, Kumar KA, et al., 2014. Clinical practice guideline: acute otitis externa, Otolaryngology-Head and Neck Surgery150(1S): S1 -S24

Sooryadas S, Deepthy BJ, 2013. Treatment of pseudomonas infected chronic otitis externa in dogs using indian "khadikraft" honey as ear drops, IJAVMS 7:12-4

Suarez JMA, Gasparrini M, Hernandez TYF, Mazzoni L, Giamperi F, 2014. The composition and biological acivity of honey: a focus on manuka honey, Foods 3:420-32

Suwu P, Kountul C, Waworuntu O, 2013. Pola kuman dan uji kepekaannya terhadap antibiotika pada penderita otitis eksterna di poliklinik tht-kl blu rsu prof. dr. r. d. kandau manado, Jurnal e-CliniC 1(1): $20-5$

Werner A, Laccourreye 0,2011 . Honey in otorhinolaryngology: when, why and how?, European Annals of Otorhinolaryngology, Head and Neck disease 128:133-7 